\title{
THE SYNANTHROPIC COMMON MOORHEN (GALLINULA CHLOROPUS) IN NORTH AFRICA: THE IMPACT OF HABITAT DEGRADATION ON BREEDING PERFORMANCES
}

\author{
Awatif Talbia, e, Laïd Touati ${ }^{\mathrm{b}, \mathrm{e}}$, Mohammed Athamniaa ${ }^{\mathrm{a}, \mathrm{e}}$, Farrah Samraoui ${ }^{\mathrm{a}, \mathrm{e}}$, Corrado Battistic and Boudjéma \\ Samraouid,e
}

\author{
aDepartment of Ecology and Environmental Engineering, University 8 Mai 1945, Guelma, Algeria; email: talbi.awatiff@gmail. \\ com; athamnia.mouh@yahoo.fr \\ ${ }^{b}$ Biology and Ecology Department, University of Constantine, Constantine, Algeria; email: laidbio@hotmail.com \\ c'Torre Flavia' LTER (Long Term Ecological Research) Station, Protected areas - Regional park Service, Città Metropolitana di \\ Roma Capitale, viale G. Ribotta, 41, 00144 Rome, Italy and Faculty of Science - University of Rome III, viale Marconi, 446, \\ 00146 Rome, Italy; email: c.battisti@cittametropolitanaroma.gov.it \\ dDepartment of Biology, University Badji Mokhtar Annaba, Annaba, Algeria; email: bsamraoui@gmail.com \\ e Laboratoire de Conservation des Zones Humides, Université 8 Mai 1945, Guelma, Algeria \\ *Corresponding author. Email: fsamraoui@gmail.com
}

\begin{abstract}
Article history
Received: 20 August 2020; accepted: 9 March 2021
\end{abstract}

\section{Keywords:}

Wetlands; Rallids; breeding success; land conversion; species' response; human encroachment

\begin{abstract}
We carried out a study on dynamics of the Common Moorhen, Gallinula chloropus, a synanthropic rallid (Aves, Gruiformes), to elucidate the adverse effects this species has possibly suffered from the markedly increased habitat degradation that has been taking place over the last decades at Boussedra Pond, north-eastern Algeria. During the period 2015-2018, this wetland-related species showed an annual $35.4 \%$ decrease in its numbers, and the number of breeding pairs, which was monitored between 2008 and 2018, experienced an annual drop of 4.9\%. The clutch size, a key determinant of breeding performance, averaged $4.7 \pm 1.0$ eggs $(\mathrm{N}=26$ clutches $)$ in 2018 and was significantly lower than those reported in previous studies. As a result of anthropogenic activities, the size of the marsh decreased by more than 50\% over the 1984-2018 period. The long-lasting shrinkage of this relict wetland was accompanied by the expansion of built-up areas $(>50 \%)$ and cultivated plots, and, also, by a marked reduction in natural both wet- and dry-land habitats in its vicinity. We suggest that the decrease in the population trend and the breeding performance of the Common Moorhen could be indicative of the species stress response to the long-lasting land conversion, pressuring the relict habitat of Boussedra Pond.
\end{abstract}

\section{INTRODUCTION}

In recent decades, important environmental changes have affected wetlands worldwide (Gibbs 2000; Sun et al. 2015). A similar adverse trend has impacted Mediterranean wetlands (de Bélair and Samraoui 1994; Benslimane et al. 2019), with consequent local-, medium- and large-scale effects on many waterbirds, using these ecosystems as wintering areas, migratory stopovers or breeding sites (Battisti et al. 2008; Paracuellos 2008). In the face of environmental perturbations, species show varying capacity of persistence, and their response may be mediated by a range of behavioral and physiological adaptations to environmental and human-induced stresses (Hofmann and Todgham 2010; Battisti et al. 2016), with inter-specific and intra-specific variations (Oliver et al. 2015).

Waterbirds respond differently to environmental changes and, in many cases, they are considered to be most suitable bio-indicators for assessing the general status of wetlands and the threats facing them (Temple and
Wiens 1989; Gregory et al. 2008; Benassi et al. 2007). The habitat use by waterbirds is primarily affected by habitat composition, structure and heterogeneity, food resources, climate, and mortality (Ogden et al. 2014).

Due to their commonness and wide distribution, rails (Gruiformes, Rallidae), which are usually associated with marshy habitats covered by dense vegetation (De Kroon 2004), are considered to be good biological models for monitoring anthropogenic (human-induced) changes in wetlands (Samraoui et al. 2015). Notably, the Common Moorhen (Gallinula chloropus) is a territorial and generalist rail, which exploits a wide spectrum of habitats ranging from rivers and canals to lakes and ponds (Wood 1974; Cramp and Simmons 1980; Talbi et al. 2020). In Northern Africa, the Common Moorhen is a sedentary species that breeds and winters in a large number of wetlands (Samraoui and Samraoui 2008; Samraoui et al. 2011), and shows high resilience to anthropogenic changes (Smith and Chow Fraser 2010; Samraoui et al. 2013). In addition, the status of the species in the region has been well documented, and many 
aspects of its life history have been described. Due to the detailed studies documenting its breeding ecology in altered habitats (Samraoui et al. 2013; Meniaia et al. 2014), the species may be considered to be a suitable bio-indicator of the ecological integrity of wetlands under severe anthropogenic stress.

Boussedra Pond (North-eastern Algeria) is an important wintering and nesting marsh for many waterbird species (Samraoui et al. 2011). This marsh is directly affected by urbanization, causing large area losses and significant disruption of the natural and functional status of the aquatic ecosystem. The unabated landfill of Boussedra Pond has led to the plant cover decline. Distinct plant communities of the marsh serve as feeding and breeding areas for the migratory or resident avifauna. However, a large number of human-induced disturbances (sensu Battisti et al. 2016) act on waterbirds (Zacchei et al. 2011). These disturbances may have implications on the breeding ecology of waterbirds, which might respond to these disturbances by modifying their ecology and behavior.

The rapid decrease in waterbird diversity has aroused worldwide concern and heightened the need for these species'conservation (Wang et al. 2018). The present study aims at enhancing our knowledge of the transformation extent that the landscape around Boussedra Pond, a relict wetland, has undergone over the 1984 2018 period. The available baseline data on breeding pairs, nesting success (2008) and winter counts (2015) of the Common Moorhen Gallinula chloropus in this severely disturbed wetland, facing an increasing number of anthropogenic threats, manifest the negative effect of the habitat deterioration on the nesting success and population dynamics of this species.

\section{METHODS}

\section{Study area}

The fieldwork was carried out at the Boussedra Pond $\left(36^{\circ} 50^{\prime} 45^{\prime \prime} \mathrm{N}, 7^{\circ} 43^{\prime} 47^{\prime \prime} \mathrm{E}\right)$, which lies within El Bouni, a suburb of the coastal town of Annaba (Figure 1). This unprotected freshwater marsh is dominated by Scirpus maritimus and Typha angustifolia. A small stand of Tamarisk trees Tamarix gallica is also found on its southern shore. The weather is typically Mediterranean with a dry and hot period between May and October and a wet period between November and April. Since 2003, the site has been used as a landfill resulting in the loss of over $30 \%$ of its former area by 2011 (Samraoui et al. 2012, 2013). Since then, the degradation of Boussedra Pond has been proceeding unabated. The site is recognized as an Important Bird Area (Fishpool and Evans 2001) due to its role as a wintering and breeding ground for the globally threatened White-headed Duck Oxyura leucocephala and Ferruginous Duck Aythya nyroca (Samraoui and Samraoui 2008).

\section{Sampling protocol}

An exhaustive sampling was carried out twice a month from December 2017 to April 2018, to identify and determine the phenological status of the Common Moorhen at Boussedra Pond. The inventory was made from two observation points overlooking the site using an ornithological telescope (KONUS-SPOT 20-40 $\times$ 60 ). An individual count was carried out in cases where the population was very close (less than $200 \mathrm{~m}$ ) and did not exceed 200 individuals. Where the population was remote or its number was fairly large, visual estimates were made (Meziane et al. 2014).

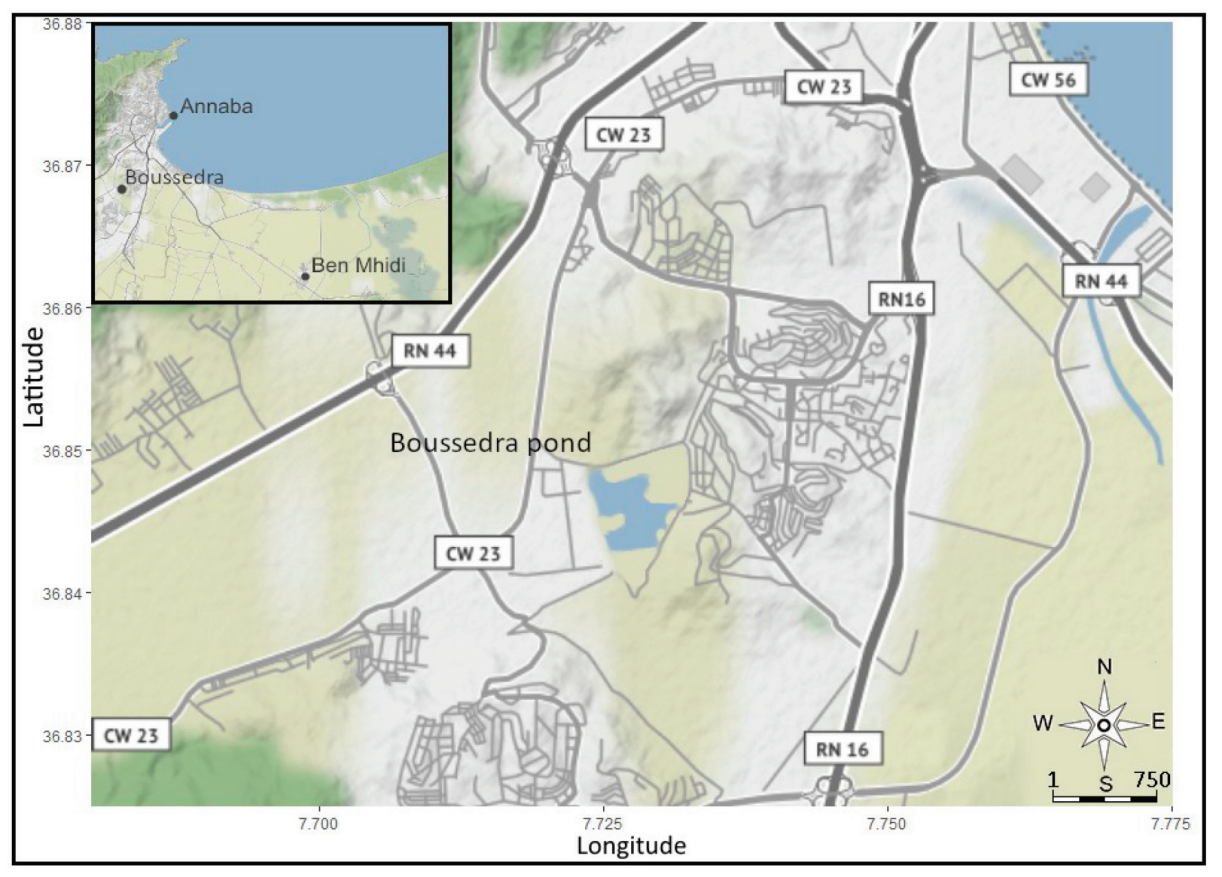

Figure 1. Map of the study area, Boussedra Pond (Algeria). 
The data were collected twice a week during the breeding season between early May and the end of July 2018. All nest positions were recorded using a Global Positioning System (GPS), and with the help of a kayak, each nest was found and labeled with a distinct code. The height of the nest above water, the water depth, and the external and internal diameters were measured.

The vegetation density (\% cover) was visually estimated in a $4 \times 4-\mathrm{m}$ square centered on the nest. Eggs were given a number, with a permanent marker. Egg length (L) and egg breadth (B) were measured to the nearest $0.1 \mathrm{~mm}$ using digital vernier calipers. Egg volume (V) was calculated using Hoyt's (1979) formula: $\left(\mathrm{V}=0.000509 * \mathrm{~L} * \mathrm{~B}^{2}\right)$. Clutches were deemed completed when the number of eggs remained unchanged between subsequent visits. The date when the first egg of a clutch was laid was used as the laying date of a nest (Lack 1950). When nests were found after the clutch was completed, the first-egg date was inferred from hatching dates with the incubation period assumed to be 22 days long. The outcome was also recorded (success, depredation or mortality due to other causes) (Huxley and Wood 1976; Samraoui et al. 2013).

\section{Land cover change and population monitoring}

The images obtained from Google Earth (for the years 1984, 1998, and 2018) were classified by Earth Observation Tools using the open-source QGIS environment (with a $10 \mathrm{~km}^{2}$ buffer zone), to provide land use and land cover (LULC) information.

Unpublished data (F. Samraoui, unpub.) allowed us to assess changes in the wintering peak population in the period 2015-2018 by calculating the annual growth rate using the formula $\left((\mathrm{f} / \mathrm{s})^{\wedge}(1 / \mathrm{t})-1\right)^{*} 100$, where $\mathrm{f}$ and $\mathrm{s}$ are the final and starting values, respectively, and $\mathrm{t}$ represents the elapsed period between the two (Touati et al. 2017). Likewise, the data for the breeding season of 2008 (Samraoui et al. 2013) allowed us to estimate changes in the number of active nests in the period 2008-2018 using the same formula.

\section{Statistical analysis}

A Generalized Linear Model (GLM) with a Poisson error distribution and a log link function was performed to test whether the clutch size could be explained by nest characteristics (egg laying date, nest height, external diameter, vegetation density and water depth). Similarly, a GLM with binomial error distribution and a logit link function was used to test whether nesting success could be explained by nest characteristics. A backward selection approach was used and the goodness of fit was evaluated using the log-likelihood of the data given the estimated parameters. Selected models were subsequently validated.
One-sample $t$-tests were conducted to test whether the recorded clutch sizes were significantly different from the mean clutch sizes previously reported at Boussedra Pond (Samraoui et al. 2013) and Lake Tonga (Meniaia et al. 2014). All statistical analyses were carried out using R (R Development Core Team 2019).

\section{RESULTS}

\section{Land conversion}

Patterns of land use and land cover (LULC) in and around Boussedra Pond,clearly indicated that between 1984 and 2018, significant land changes had occurred (Figure 2a,b). In the surrounding area of Boussedra Pond, built-up areas had doubled in size, their percentage of the total area increasing from $25.5 \%$ to $50.2 \%$. At the same time, the surface occupied by grassland shrank from $69.9 \%$ to $47.6 \%$. The decline in natural vegetation is even more pronounced as the land converted to agricultural use, a phenomenon on the increase over the same period (1984-2018), was recorded as "land under vegetation". Thus, both built-up and agricultural areas expanded at the expense of natural terrestrial vegetation. Similarly, the relict wetland, Boussedra Pond, also incurred considerable modifications, with the total marsh area shrinking by more than $50 \%$ (from $4.7 \%$ to $2.2 \%$ ) between 1984 and 2018. This modification corresponded to the conspicuous loss of water and aquatic vegetation within the marsh (Table 1, Figure 2a,b).

Table 1. Size area of Boussedra pond, terrestrial vegetation and built areas all in $\mathrm{m}^{2}$ in the study years $(1984,2008,2018)$.

\begin{tabular}{|l|c|c|c|}
\hline \multicolumn{1}{|c|}{ Terrain } & 1984 & 2008 & 2018 \\
\hline Boussedra Pond $\left(\mathrm{m}^{2}\right)$ & 470,000 & 290,000 & 220,000 \\
\hline Terrestrial vegetation $\left(\mathrm{m}^{2}\right)$ & $6,984,757$ & $5,903,806$ & $4,755,830$ \\
\hline Built-up areas $\left(\mathrm{m}^{2}\right)$ & $2,545,243$ & $3,806,194$ & $5,024,170$ \\
\hline
\end{tabular}

\section{Winter abundance and phenology}

The number of moorhens rose from December 2017 to February 2018 peaking at 77 individuals before declining (Figure 3). Compared to the previous peak of 286 birds recorded in 2015, the recent peak represents a decline of $35 \%$ in total abundance.

\section{Nest characteristics and breeding phenology}

All the nests, 26 in number, in 2018 were recorded within Typha angustifolia stands (Table 2). Egg laying started in May and ended on 19 July, with a peak observed on 28 June (Figure 4a). When compared to the previous survey of breeding pairs in 2008 (Samraoui et al. 2013), the recorded number of nests represents a drop of $4.9 \%$. 

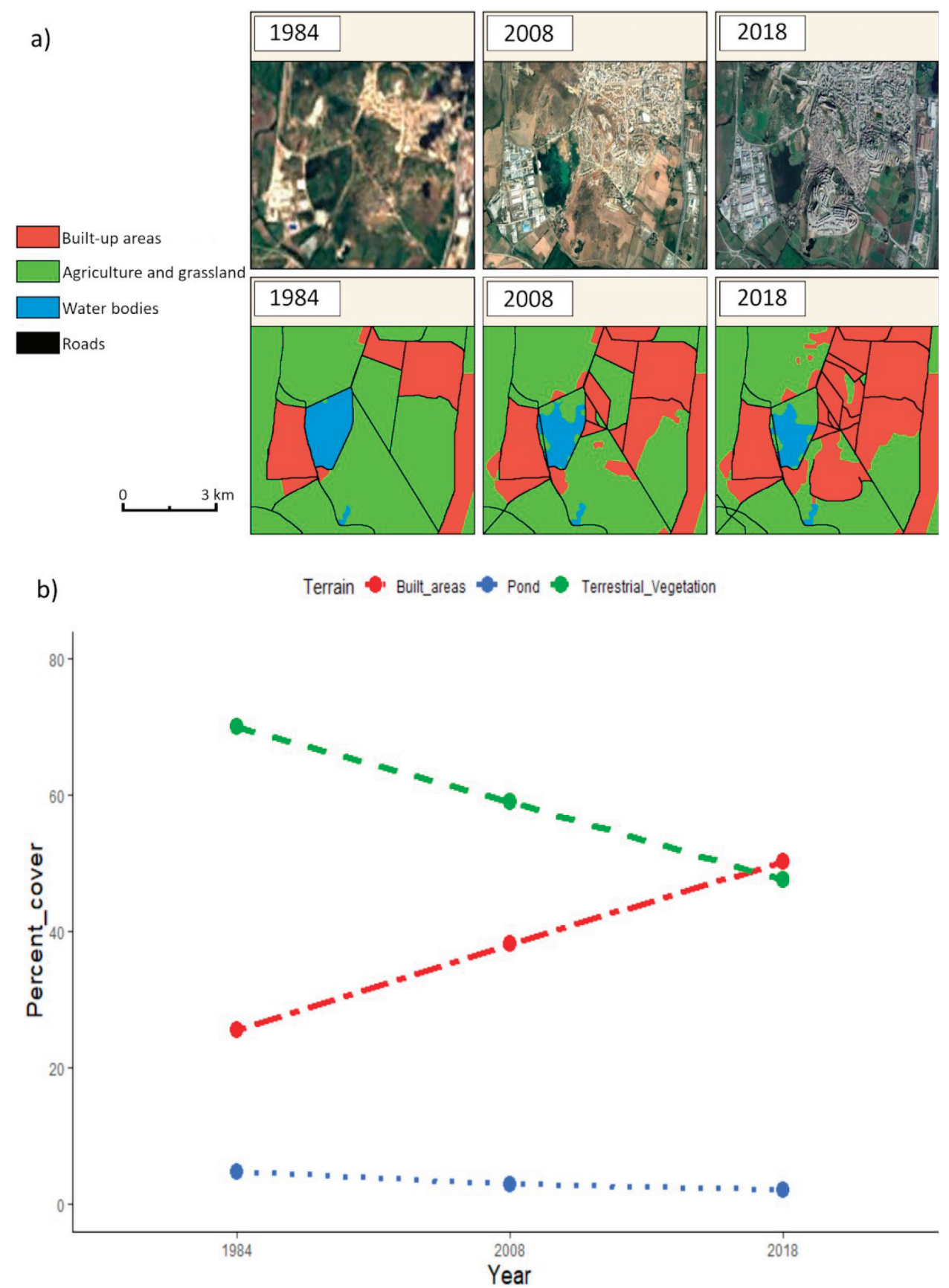

Figure 2. Changes in landscape cover in a $10 \mathrm{~km}^{2}$ buffer zone around Boussedra Pond in 1984, 2008, and 2018 (a), and percent cover $(\%)$ change $(b)$.

Table 2. Nesting sites and nest characteristics of Common Moorhen at Boussedra Pond in 2018.

\begin{tabular}{|l|c|c|c|}
\hline & Mean $\pm \mathrm{sd}$ & Min & Max \\
\hline Characteristics of nesting sites & & & \\
Water depth $(\mathrm{cm})$ & $59.73 \pm 17.01$ & 22 & 88 \\
Water/nest distance $(\mathrm{cm})$ & $35.23 \pm 15.77$ & 10 & 68 \\
Vegetation height $(\mathrm{cm})$ & $158.77 \pm 41.96$ & 58 & 250 \\
Density $(\%)$ & $57.50 \pm 20.46$ & 20 & 95 \\
\hline Nest measurements & & & \\
External diameter $(\mathrm{cm})$ & $20.54 \pm 3.29$ & 14 & 30 \\
Internal diameter $(\mathrm{cm})$ & $13.46 \pm 2.45$ & 9 & 20 \\
Height $(\mathrm{cm})$ & $9.42 \pm 4.56$ & 4 & 20 \\
\hline
\end{tabular}

Egg characteristics, clutch size and hatching success in 2018

The mean recorded egg length, breadth and volume $(n=$ 118 eggs) was $43.3 \pm 1.9 \mathrm{~mm}, 30.6 \pm 1.5 \mathrm{~mm}$ and 20.8 $\pm 2.5 \mathrm{~cm}^{3}$, respectively (Table 3 ). The mean clutch size was $4.7 \pm 1.0$ eggs (range $1-9 ; n=26$ clutches) with 4 egg-bearing nests being the most prevalent (Figure $4 b$ ). We also compared the recorded clutches with the mean values (6.7 and 7.0) reported by Samraoui et al. (2013) at Boussedra and Meniaia et al. (2014), respectively. Both one-sample $t$-tests were associated with statistically significant effects $(t(25)=-5.0, p=3.8 \mathrm{e}-05)$ and 


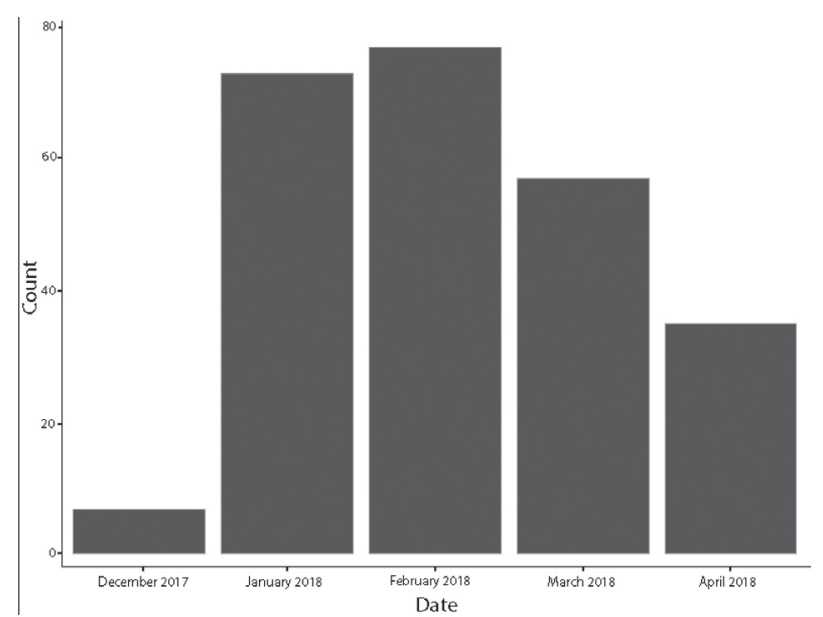

Figure 3. Monthly changes of wintering Common Moorhen at Boussedra Pond during the season 2017-2018.
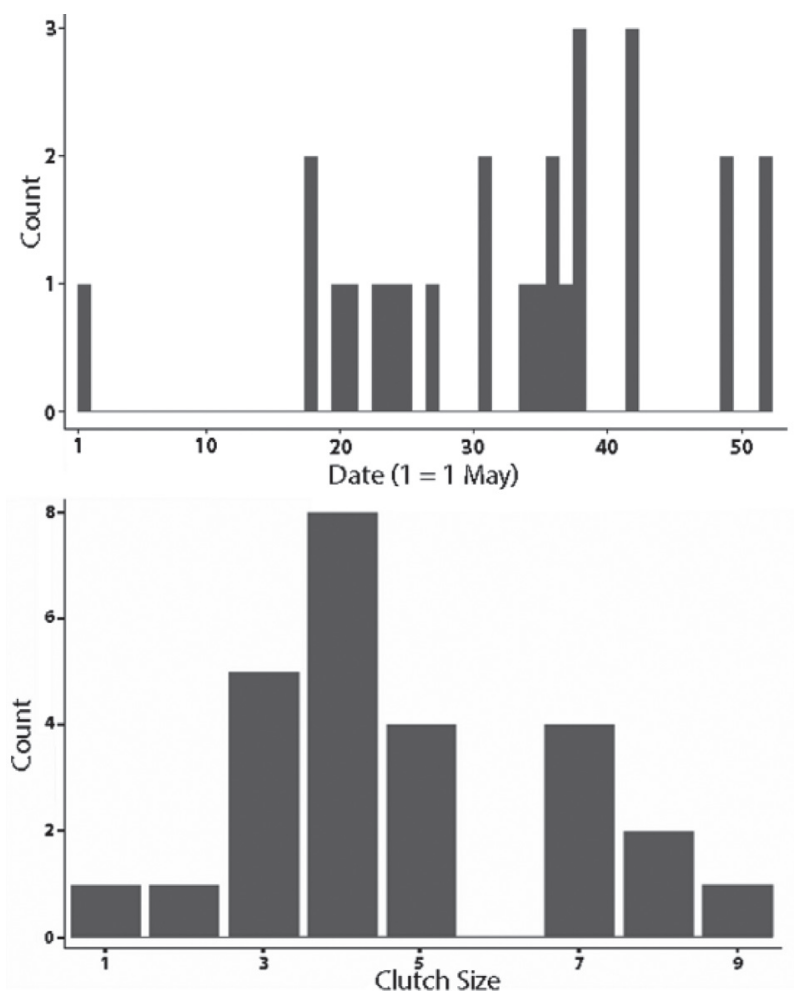

Figure 4. Distribution of egg laying date (a) and clutch size (b) of Common Moorhen at Boussedra Pond in 2018.

$(t(25)=-5.8, p=5.4 \mathrm{e}-06)$, respectively. Thus, the clutch sizes recorded by us were significantly smaller than those reported by Samraoui et al. (2013) and Meniaia et al. (2014).

During the study period, the overall nesting success was $69 \%$ (nests with at least one chick that survived until it left the nest) and the hatching rate was $71 \%(\mathrm{n}=18)$. Nest failure was mainly due to predation $(31 \%)$ by the Viperine Snake Natrix maura and other unidentified predators. The Poisson GLM showed no seasonal variation in clutch size $(p=0.11)$, whereas, as indicated by the binomial GLM, nesting success showed a marginally positive trend with delayed egg laying $(p=0.05)$. Nest characteristics (nest height, external diameter, vegetation density and water depth) had no significant impact on clutch size or breeding success.

Table 3. Egg measurements of Common Moorhen at Boussedra Pond in 2018 ( $\mathrm{N}=118$ clutches $)$.

\begin{tabular}{|l|c|c|c|}
\hline & Mean $\pm \mathrm{sd}$ & Min & Max \\
\hline Egg measurements & & & \\
Length $(\mathrm{mm})$ & $43.33 \pm 1.90$ & 39.91 & 48.51 \\
Breadth $(\mathrm{mm})$ & $30.62 \pm 1.52$ & 27.44 & 36.96 \\
Volume $\left(\mathrm{cm}^{3}\right)$ & $20.76 \pm 2.53$ & 15.82 & 30.13 \\
\hline
\end{tabular}

\section{DISCUSSION}

Boussedra Pond and the landscape surrounding it have changed markedly over the 1984-2018 period. Human encroachment into the area surrounding this relict wetland, as reflected by built-up areas and agricultural land, has significantly expanded impacting on the natural terrestrial vegetation. Besides providing various ecosystem services (pollination, pest control, soil stabilization and carbon stocking) (Bolin 1977), terrestrial vegetation shelters nesting birds such as Mallard Anas platyrhynchos (Fouzari et al. 2018). Thus, the loss of terrestrial vegetation has indirect but serious implications for the ecological integrity of the marsh (Stewart et al. 2016).

In the period 1984-2018, the marsh was also directly affected by human activity and therefore sustained heavy damage: its size halved. The construction of the university campus at the town El Bouni proved instrumental in reducing the marsh land area, as the soil excavated during construction was dumped in the marsh. Both areas of open water and aquatic vegetation shrank with consequential effects on breeding birds and invertebrates (Tscharntke 1992). The combined effect of all these changes, leading to the loss of habitat heterogeneity and impairment of its functioning, has been shown to have deleterious consequences on Mediterranean wetlands and birds breeding therein (Paracuellos 2008; Battisti et al. 2008).

The Common Moorhen showed a hump-shaped pattern in abundance during the wintering season 2017-2018, with a peak in February when the local population of this species was composed of residents and wintering/ passage migrant birds. The abundance progressively decreased as a result of both extrinsic (departure of wintering birds) and intrinsic factors (sampling bias: the elusive behavior of individuals during the breeding period makes them less noticeable). When compared to the wintering season of 2014-2015 (unpublished), the Common Moorhen population exhibited a marked downward trend, declining annually by $35.4 \%$, an unsus- 
tainable trend that requires prompt mitigating measures (e.g. halting of poaching and landfilling).

The egg-laying date is an important trait that is frequently used in reproductive studies (e.g. Krebs et al. 2002; Both et al. 2005; Fouzari et al. 2015). The onset of egg-laying at Boussedra in 2018 was recorded in May and lasted until mid-June, and the peak in the second half of June was relatively late compared to those previously recorded at Boussedra Pond and Lake Tonga (Samraoui et al. 2013: in mid-May; Meniaia et al. 2014: early May and mid-May), suggesting the late arrival of breeding pairs (Samraoui et al. 2013). However, this discrepancy in the timing of egg-laying deserves further investigation.

In total, 26 Common Moorhen's nests were found located in beds of Typha angustifolia, showing a clear preference for lesser bulrush and dense vegetation, which provide nesting cover and trophic resources (Samraoui et al. 2013; Meniaia et al. 2014). Our findings on nest sites correspond with the data obtained by Samraoui et al. (2013) from neighboring sites in Algeria and Forman and Brain (2004) in Northern Europe. If past breeding surveys are used as baseline data, the present number of breeding pairs is exhibiting a downwards trend (-4.9\%), which is likewise unsustainable and may soon rule out the Common Moorhen as a breeding species at Boussedra Pond.

Our data on the mean egg length and breadth were well within the means and ranges cited in the literature from Europe (north western Italy: length $44.3 \pm 1.8$, breadth $30.2 \pm 1.4$, Fenoglio et al. 2003; UK: length $44.97 \pm 0.04$, breadth $32.05 \pm 0.02$, Forman and Brain 2004) and from Algeria (Boussedra: length $43.5 \pm 1.6$, breadth $30.1 \pm 1.2$ / Tonga : length $42.9 \pm 1.3$, breadth $30.2 \pm 0.8$, Samraoui et al.2013; Tonga: length $42.49 \pm$ 1.72 , breadth $29.60 \pm 1.24$, Meniaia et al. 2014). Egg size may be influenced by a range of factors including maternal age, maternal quality and clutch size, and, also, by the fact whether a clutch is a replacement or not (Fjeldså 2004; Saether 1990). However, our data suggest that there is no latitudinal gradient influence on the egg size of Common Moorhens. Similarly, we could not detect the hypothetical impact that a change in habitat at Boussedra Pond could make on egg size.

In contrast to egg size, the overall mean clutch size recorded in the present study was significantly smaller than the values previously reported from Boussedra Pond (6.7 $\pm 2.1, \mathrm{~N}=14$ clutches: Samraoui et al. 2013) and Lake Tonga $(7.03 \pm 2.5, \mathrm{n}=58$ clutches: Meniaia et al. 2014). As the marsh has decreased considerably in size over the last three decades, the population density of moorhens might have increased accordingly, leading to a decreased mean clutch size due to intraspecific competition. This density-dependent regulation combined with the persistent degradation of the marsh may lead to the extirpation of moorhens as it happened in the case of such marsh specialists as the Little Bittern Ixobrychus minutus and Marsh Harrier Circus aeruginosus (B. Samraoui, pers. obs.). Clutch size is a key determinant of nesting success (Högstedt 1981) and a reliable indicator of habitat quality, including quality and quantity of trophic resources (Coulson 1999).

In our study, the hatching success was within the range recorded previously at Boussedra Pond and Lake Tonga (Samraoui et al. 2013; Meniaia et al. 2014). Differences may result from variation factors such as water depth and predation (Salathé 1986, 1987), habitat characteristics (e.g. high density of vegetation), the presence of humans and related threats (Salathé 1987), physiological nutrient reserves and individual fitness (Hepp 1984), and finally, food supply and the timing of breeding (Perdeck and Cavé 1992; Brinkhoff et al. 1993; Brinkhoff 1997; Brinkhoff and Cavé 1997).

Regarding the disturbances to nesting birds, we recorded a relatively high rate of nest failure in late spring, a recurrent phenomenon coinciding with the beginning of the school break. During this period, human intrusion (e.g. trampling, active search for nests by children) adversely affects the fitness of waterbirds by disturbing adults and chicks or facilitating predation (Anderson and Keith 1980; Carney and Sydeman 1999; Voorbergen et al. 2012). This wetland is close to an urban area, which leaves nests exposed to the threat of failure. However, most nests probably failed due to predation by the Viperine Snake Natrix maura, which is a common snake predator at Boussedra Pond (Battisti et al. 2006, Meniaia et al. 2014). The loss of plant cover may contribute to the vulnerability of clutches to predation (Samraoui et al. 2013).

As for the water level in 2018, our results indicate that the breeding success was not associated with water depth. However, it is likely that a high-water level, would impede human-induced disturbances and predation events (McRae 1997; Angelici et al. 2012; Meniaia et al. 2014).

This study has presented the first assessment of the extent of land conversion in and around an urban marsh, Boussedra Pond, now reduced to a relict wetland. It has also provided an overview of the recent status and breeding performance of the Common Moorhen, considered as a resilient rallid, whose breeding ecology is relatively well known. Compared to a recent past (2008 and 2015), the Common Moorhen has been exhibiting a decrease in its wintering and breeding populations at Boussedra Pond, while its breeding performance has been declining, suggesting a possible link with severe anthropogenic impacts on its habitat. Further monitoring of this relict wetland may inform about future population 
trends of waterbirds, and their responses to a rapidly deteriorating environment (Samraoui et al. 2012).

\section{COMPETING INTEREST}

The authors declare that they have no competing interest.

\section{ACKNOWLEDGMENTS}

We are most grateful to two anonymous reviewers for their helpful comments. We also thank Kenz Raouf Samraoui for help with maps. This study was supported by the Algerian Ministère de l'Enseignement Supérieur et de la Recherche Scientifique (MESRS).

\section{REFERENCES}

Anderson, D. W., and J. O. Keith. 1980. The human influence on seabird nesting success: conservation implications. Biological Conservation 18: 65-80. http://dx.doi. org/10.1016/0006-3207(80)90067-1

Angelici, C., F. Marini, C. Battisti, S. Bertolino, D. Capizzi, and A. Monaco. 2012. Cumulative impact of rats and Coypu on nesting waterbirds: first evidences from a small Mediterranean wetland (central Italy). Vie et Milieu 62: 137-141.

Battisti, C., C. Aglitti, A. Sorace, and M. Trotta. 2006. Water level decrease and its effects on the breeding bird community in a remnant wetland in central Italy. Ekológia Bratislava 25: 252-263.

Battisti, C., L. Luiselli, D. Pantano, and C. Teofili. 2008. On threats analysis approach applied to a Mediterranean remnant wetland: Is the assessment of human-induced threats related to different level of expertise of respondents? Biodiversity and Conservation 17: 1529-1542. http://dx.doi.org/10.1007/s10531-008-9360-1

Battisti, C., G. Poeta, and G. Fanelli. 2016. An introduction to Disturbance Ecology. A road map for wildlife management and conservation. Springer, Switzerland.

Benassi, G., C. Battisti, and L. Luiselli. 2007. Area effect on bird species richness of an archipelago of wetland fragments in Central Italy. Community Ecology 8: 229-237. http://dx.doi.org/10.1556/ComEc.8.2007.2.9

Benslimane, N., K. Chakri, D. Haiahem, A. Guelmami, F. Samraoui, and B. Samraoui. 2019. Anthropogenic stressors are driving a steep decline of hemipteran diversity in dune ponds in northeastern Algeria. Journal of Insect Conservation 23: 475-488.

Bolin, B. 1977. Changes of land biota and their importance for the carbon cycle. Science 196: 613-615.http:// dx.doi.org/10.1126/science.196.4290.613
Both, C., T. Piersma, and S. P. Roodbergen. 2005. Climatic change explains much of the 20th century advance in laying date of Northern Lapwing Vanellus vanellus in The Netherlands. Ardea 93: 79-88.

Brinkhof, M. W. 1997. Seasonal variation in food supply and breeding success in European Coots Fulica atra. Ardea 85: 51-66.

Brinkhof, M. W., and A. J. Cavé. 1997. Food supply and seasonal variation in breeding success: an experiment in the European coot. Proceedings of the Royal Society of London. Series B: Biological Sciences 264: 291-296.

Brinkhof, M. W., A. J. Cavé, F. J. Hage, and S. Verhulst. 1993. Timing of reproduction and fledging success in the coot Fulica atra: evidence for a causal relationship. Journal of Animal Ecology 62: 577-587. http://dx.doi. org/10.2307/5206

Carney, K. M., and W. J. Sydeman. 1999. A review of human disturbance effects on nesting colonial waterbirds. Waterbirds 22: 68-79. http://dx.doi. org/10.2307/1521995

Coulson, J. C. 1999. Variation in clutch size of the common eider: a study based on 41 breeding seasons on Coquet Island, Northumberland, England. Waterbirds 22: 225-238. http://dx.doi.org/10.2307/1522211

Cramp, S., and K. E. L. Simmons. 1980. The Birds of the Western Palearctic. Vol. 2. Oxford: Oxford University Press. 696 pp.

de Bélair, G., and B. Samraoui. 1994. Death of a Lake: Lac Noir in Northeastern Algeria. Environmental Conservation 21: 169-172.

De Kroon, G. H. 2004. A comparison of two European breeding habitats of the Water Rail Rallus aquaticus. Acta Ornithologica 39: 21-27.

Fenoglio, S., M. Cucco, and G. Malacarne. 2003. Moorhen Gallinula chloropus females lay eggs of different size and beta-carotene content. Ardea 91: 117-121.

Fjeldså, J. 2004. The Grebes: Podicipedidae. Oxford: Oxford University Press. 246 pp.

Fishpool, L.D., and M. I. Evans. 2001. Important Bird Areas in Africa and associated islands: Priority sites for conservation. BirdLife International. Cambridge.

Forman, D.W., and P. F Brain. 2004. Reproductive strategies used by moorhens (Gallinula chloropus) colonizing an artificial wetland habitat in south Wales. Journal of Natural History 38: 389-401.

Fouzari, A., F. Samraoui,A. H. Alfarhan, and B. Samraoui. 2015. Nesting ecology of Ferruginous Duck Aythya nyroca in northern Algeria. African Zoology 50: 99-305.

Fouzari, A., F. Samraoui, and B. Samraoui. 2018. The breeding ecology of Mallard Anas platyrhynchos at Lake Tonga, northeastern Algeria. Ostrich 89: 315-320.

Gibbs, J. P. 2000. Wetland loss and biodiversity conservation. Conservation Biology 14: 314-317. http://dx.doi. org/10.1046/j.1523-1739.2000.98608.x 
Gregory, R.D., P. Vořišek, D.G. Noble, A. Van Strien, A. Klvaňová, M. Eaton, A. W. G. Meyling, A. Joys, R.P.B. Foppen, and I. J. Burfield. 2008. The generation and use of bird population indicators in Europe. Bird Conservation International 18: S223-S244.http:// dx.doi.org/10.1017/S0959270908000312

Hepp, G. R. 1984. Dominance in wintering Anatinae: potential effects on clutch size and time of nesting. Wildfowl 35: 132-134.

Hofmann, G. E., and A. E. Todgham. 2010. Living in the now: physiological mechanisms to tolerate a rapidly changing environment. Annual Review of Physiology 72: 127-145. http://dx.doi.org/10.1146/annurev-physiol-021909-135900

Högstedt, G. 1981. Effect of additional food on reproductive success in the Magpie (Pica pica). Journal of Animal Ecology 50: 219-229. http://dx.doi.org/10.2307/4041

Huxley, C. R., and N. A. Wood. 1976. Aspects of the breeding of the moorhen in Britain. Bird Study 23: 1-10. http://dx.doi.org/10.1080/00063657609476478

Krebs, E. A., D. J. Green, M. C. Double, and R. Griffiths. 2002. Laying date and laying sequence influence the sex ratio of crimson rosella broods. Behavioral Ecology and Sociobiology 51:447-454. http://dx.doi.org/10.1007/ s00265-002-0459-1

Lack, D. 1950. The breeding seasons of European birds. Ibis 92: 288-316.http://dx.doi.org/10.1111/j.1474-919X.1950.tb01753.X

McRae, S. B. 1997. A rise in nest predation enhances the frequency of intraspecific brood parasitism in a moorhen population. Journal of Animal Ecology 66: 143-153. http://dx.doi.org/10.2307/6017

Meniaia, Z., F. Samraoui, A. H. Alfarhan, and B. Samraoui. 2014. Nest-site selection, breeding success and brood parasitism in the common moorhen Gallinula chloropus in Algeria. Zoology and Ecology 24: 305-313.

Meziane, N., F. Samraoui, B. Samraoui. 2014. Status and diurnal activity budget of non-breeding White-headed Ducks Oxyura leucocephala in Algeria. Ostrich 85: 177-184.

Ogden, J. C., J. D. Baldwin, O. L. Bass, J. A. Browder, M. I. Cook, P. C. Frederick, P. E. Frezza, R. A. Galvez, A. B. Hodgson, K. D. Meyer, L. D. Oberhofer, A. F. Paul, P. J. Fletcher, S. M. Davis, and J. J. Lorenz. 2014. Waterbirds as indicators of ecosystem health in the coastal marine habitats of southern Florida: 1. Selection and justification for a suite of indicator species. Ecological indicators 44: 148-163. http://dx.doi. org/10.1016/j.ecolind.2014.03.007

Oliver, T. H., M. S. Heard, N. J. Isaac, D. B. Roy, D. Procter, F. Eigenbrod, R. Freckleton, A. Hector, C. D. L. Orme, O. L. Petchey, V. Proença, D. Raffaelli, K. B. Suttle, G. M. Mace, B. M. López, B. A. Woodcock, and J. M. Bullock. 2015. Biodiversity and resilience of ecosystem functions. Trends in Ecology and Evolution 30: 673-684. http://dx.doi.org/10.1016/j.tree.2015.08.009
Paracuellos, M. 2008. Effects of long-term habitat fragmentation on a wetland bird community. Revue d'écologie 63: 1-12.

Perdeck, A. C., and A. J. Cavé. 1992. Laying date in the coot: effects of age and mate choice. Journal of Animal Ecology 61: 13-19. http://dx.doi.org/10.2307/5504

R Development Core Team. 2019. R: A Language and Environment for Statistical Computing. Vienna, Austria.

Sæther, B. E. 1990. Age-specific variation in reproductive performance of birds. Current Ornithology 7: 251-283.

Salathé, T. 1986. Habitat use by Coots nesting in a Mediterranean wetland. Wildfowl 37: 163-171.

Salathé, T. 1987. Crow predation on Coot eggs - Effects of investigator disturbance, nest cover and predator learning. Ardea 75: 221-229.

Salathé, T., and V. Boy. 1987. Territoriality and time budget of breeding Coots. Wildfowl 38: 70-76.

Samraoui, B., and G. de Bélair. 1997. The Guerbes- Senhadja wetlands (NE Algeria). Part I: an overview. Ecologie 28: 233-250.

Samraoui, B., and F. Samraoui. 2008. An ornithological survey of the wetlands of Algeria: important Bird Areas, Ramsar sites and threatened species. Wildfowl 58: 71-98.

Samraoui, F., A. H. Alfarhan, K. A. Al-Rasheid, and B. Samraoui. 2011. An appraisal of the status and distribution of waterbirds of Algeria: indicators of global changes? Ardeola 58: 137-163. http://dx.doi.org/10.13157/ arla.58.1.2011.137

Samraoui, F., R. Nedjah, A. Boucheker, A. H. Alfarhan, and B. Samraoui. 2012. Breeding ecology of the Little Bittern Ixobrychus minutus in northeast Algeria. Bird Study 59: 496-503.

Samraoui, F., A. H. Alfarhan, and B. Samraoui. 2013. Status and breeding ecology of the Common Moorhen Gallinula chloropus in Algeria. Ostrich 84: 137-144. http:// dx.doi.org/10.2989/00306525.2013.823130

Samraoui, F., R. Nedjah, A. H. Alfarhan, and B. Samraoui. 2015. An overview of the Rallidae of Algeria with particular reference to the breeding ecology of the Purple Swamp-Hen Porphyrio porphyrio. Wetlands Ecology and Management 23: 505-517. http://dx.doi. org/10.1007/s11273-014-9404-0

Smith, L. A., and P. Chow-Fraser. 2010. Impacts of adjacent land use and isolation on marsh bird communities. Environmental Management 45:1040-1051. http://dx.doi. org/10.1007/s00267-010-9475-5

Stewart, R. I. A., G. K. S. Andersson, C. Brönmark, B. K. Klatt, L. A. Hansson, V. Zülsdorff, and H. G. Smith. 2016. Ecosystem services across the aquatic-terrestrial boundary: Linking ponds to pollination. Basic and Applied Ecology 18: 13-20. http://dx.doi.org/10.1016/j. baae.2016.09.006

Sun, Z., W. Sun, C. Tong, C. Zeng, X. Yu, and X. Mou. 
2015. China's coastal wetlands: Conservation history, implementation efforts, existing issues and strategies for future improvement. Environmental International 79: 25-41. http://dx.doi.org/10.1016/j.envint.2015.02.017

Talbi, A., F. Samraoui, B. Samraoui, F. Zullo, and C. Battisti. 2020. Habitat selection of Coot (Fulica atra) and Moorhen (Gallinula chloropus) in a remnant Mediterranean wetland (Italy): Implications for conservation. Lakes \& Reservoirs: Research \& Management 25: 413-418. http://dx.doi.org/10.1111/lre.12347

Temple, S. A., and J. A. Wiens. 1989. Bird populations and environmental changes: can birds be bio-indicators. American Birds 43: 260-270.

Touati, L., R. Nedjah, F. Samraoui, A.H. Alfarhan, L. Gangoso, J. Figuerola, and B. Samraoui. 2017. On the brink: status and breeding ecology of Eleonora's Falcon Falco eleonorae in Algeria. Bird Conservation International 27: 594-606. http://dx.doi.org/10.1017/ S0959270916000484
Tscharntke, T. 1992. Fragmentation of Phragmites habitats, minimum viable population size, habitat suitability, and local extinction of moths, midges, flies, aphids, and birds. Conservation Biology 6: 530-536. http://dx.doi. org/10.1046/j.1523-1739.1992.06040530.x

Voorbergen, A., W. F. De Boer, and L. G. Underhill. 2012. Natural and human-induced predation on Cape Cormorants at Dyer Island. Bird Conservation International 22: 82-93. http://dx.doi.org/10.1017/ S0959270912000032

Wang, X., F. Kuang, K. Tan, and Z. Ma. 2018. Population trends, threats, and conservation recommendations for waterbirds in China. Avian Research 9: 14. http://dx.doi. org/10.1186/s40657-018-0106-9

Wood, N. A. 1974. The breeding behaviour and biology of the Moorhen. British Birds 67: 137-158.

Zacchei, D., C. Battisti, and G. M. Carpaneto. 2011. Contrasting effects of water stress on wetland-obligated birds in a semi-natural Mediterranean wetland. Lakes \& Reservoirs: Research \& Management 16: 281-286. 